\title{
Trends of Industry-Leading Biotechnology Stocks During COVID-19
}

\author{
Navia Zhang ${ }^{1}$ and Meredith Haskins ${ }^{\#}$ \\ ${ }^{1}$ Hong Kong International School, Hong Kong \\ \#Advisor
}

ABSTRACT

The 2019-nCoV coronavirus has significantly impacted the macroeconomic outlook for countries across the world. The biotechnology sector experienced a relatively positive stock price outlook, which corroborates the trends exhibited by biotechnology stocks in previous pandemics such as SARS (2003) and AH1N1 (2009). During the COVID-19 pandemic, vaccine roll-out rates have been more efficient than in any other pandemic, as companies today are more experienced in combating the time constraint to create vaccines. Gilead Sciences Inc. saw its shares rise 18\% after developing the first FDA-approved COVID-19 vaccine, 'remdesivir'. In contrast, AstraZeneca's shares fell 2.28\% in 2021 after its vaccine underwent investigations into blood-clotting side effects and subsequent suspension from several countries. Companies developing mRNA vaccines like Moderna, BioNTech, and Pfizer witnessed surges in share prices ranging from $10 \%$ to $20 \%$. Many newer biotech companies such as Genexie, Sanovi, OnoSec, and Vaxart have also developed vaccines for COVID-19. Share prices are more volatile for these less-established companies. This paper observes how developing new technologies obtaining FDA approvals, gaining publicity, staging clinical trials, and several other complex factors have profound impacts on the stock prices of these biotechnology companies.

Introduction

\section{Introduction}

Towards the end of 2019, the city of Wuhan in the Hubei Province of China erupted with the first incidence of what has now become a raging global pandemic. To date, what was first known as the novel coronavirus 2019-nCoV-now more commonly referred to as COVID-19, has affected 175,987,176 people across the globe, leaving a death toll of $3,811,561$ in its wake (World Health Organization, 2021). Efforts to battle the significant ramifications of this deadly virus on the lives of individuals, financial markets and industries, and global economies have been detrimental to the financials of many industries.

The biopharmaceuticals industry has been a key contributor to these efforts and was at the epicenter of "global attention" since the onset of the pandemic, providing crucial scientific research and technical capacities (Sharma \& Saiyed, 2021). Biotechnology, a term often associated with cutting-edge, technology-based gene modification, was initially coined by agriculturalist Karl Ereky in 1919 (UW Biotechnology, 2021). Biotechnology is used in the medical sector to create vaccines, antibodies, and other pharmaceutical medicines (Padhy, Song, \& Mahapatra, 2020). By analyzing a drug on its molecular level, scientists can discover chemical pathways that ensure accuracy, efficiency, and maximized yield when producing these drugs.

While global economies have taken a hit and most companies have seen dips in stock prices, industry-leading biotechnology companies saw their stock prices soar. Immense scrutiny of research, clinical trials, regulatory authority approvals, and the pressure to deliver vaccines on an unprecedented early deadline has led to surging competition among the biotech firms. Gilead Sciences, Pfizer, Moderna, and Johnson \& Johnson are emerging as market leaders (Grandview Research, 2021). This paper analyzes the impact of these pandemics on trends of leading biotechnology 
stocks with reference to the macroeconomic and financial conditions of the current global pandemic and the SARS (2002-2003) and H1N1 (2009) pandemics.

\section{How do the previous viral outbreaks compare to COVID 19 - An overview}

The COVID-19 pandemic, although unprecedented in several aspects, is not the first pandemic the world has seen in this millennium. The 2003 outbreak of SARS, or severe acute respiratory syndrome, was the first pandemic of the 21st century (LeDuc \& Barry, 2004). The outbreak first hit the Guangdong Province of China in the fall of 2002, following which it spread to 29 countries, including Hong Kong, Singapore, Vietnam, and Canada. However, unlike the current global outbreak, Asian governments were able to contain the virus quicker than expected (Donald \& Yiping, 2004). As a result, SARS was brought under control within seven months from its first occurrence (Cherry \& Krogstad, 2004). The impact was significantly less severe than predicted to be. Regardless, ramifications of the epidemic were felt throughout various sectors such as travel and tourism, hospitality, and retail (Smith \& Keogh-Brown, 2008). Even the economies of countries that were not hit with a large number of cases were affected either through decreased tourism due to heightened safety levels, or due to their proximity to heavily impacted countries. Hong Kong experienced a GDP loss of around US\$ 3.7 billion over the first and second quarters of 2003, and China's earnings from domestic tourism suffered a loss of around US\$ 3.5 billion during the SARS outbreak (Smith \& Keogh-Brown, 2008). Furthermore, Hong Kong, being one of the most severely affected nations, saw its hotel occupancy decline from $82.3 \%$ to $26.7 \%$ from the 2 nd to the 3 rd quarter of 2003 , air passenger traffic fall by $11 \%$ in May of the same year, and retail sales dip by $15.2 \%$ in April (Barua, 2020).

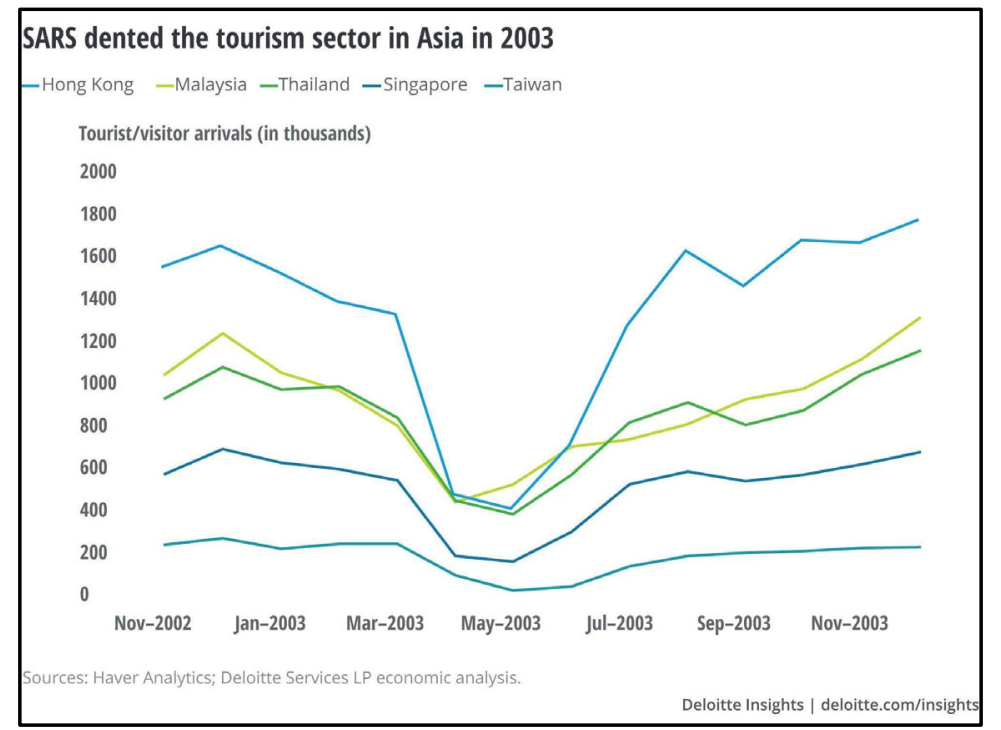

Fig 1. Decline in Tourism during SARS 2003.

Another pandemic that occurred within the last decade was the H1N1 influenza outbreak. Before April of 2009, the AH1N1 virus hadn't been identified as a cause for influenza infections in the human population (World Health Organisation, 2021). However, 214 different countries and territories had reported confirmed cases of the infection by the time WHO declared the outbreak as the source for the first global flu pandemic in 40 years (Smith \& Keogh \& Brown, 2013). According to a Journal of Preventive Medicine and Hygiene report, the "quadruple reassortant virus" is a combination of a virus originating from humans, two swine-originated viruses, and one avian-originated virus (Baldo, Bertoncello, \& Cocchio, 2016). The AH1N1 virus spread rapidly unlike the identifiable ones in circulation then. Additionally, the seasonal flu vaccines were ineffective in offering protection against the strain (CDC, n.d.). 6.6.\% of South Korea's population was impacted, leading to socio-economic costs amounting to $\$ 1.09$ billion or about 
0.14\% of South Korea's total GDP, of which 29.6\% were direct medical costs (Kim, Yoon, \& Oh, 2013). Hong Kong witnessed a sharp decline in tourism during the 2nd quarter of 2009 (Barua, 2020). Fortunately, like the SARS outbreak, the economic costs of the H1N1 influenza outbreak were relatively low.

While there are several similarities between the 2003, 2009, and the 2019 pandemics concerning the root causes, such as the public's perception of associated risks of the virus and the influence of institutional intervention strategies, there are stark differences between the various outbreaks as well. In contrast to traditional industry practices and norms, biotechnology and pharmaceutical companies have been operating at unprecedented speeds to roll out vaccines using experimental technologies and platforms (Agrawal, Ahlawat, \& Dewhurst, 2021). Gaining momentum faster than SARS (Forum, 2020), the high velocity of the new virus caused economic implications of the pandemic to be felt more intensely than those earlier in the 21 st century. The initial supply-side impact of the COVID-19 pandemic was a stagflation recession. Due to lockdowns causing factory closures across the globe, low supply output raised prices, and the economy experienced an inflation (Barzani \& Maital, 2020). As economies began to open up, the central bank pumped money into the market, lowering interest rates to stimulate demand, which may further aggravate inflation. Countries facing multiple waves of COVID-19 and those with high unemployment faced demand contraction as consumers cut back on expenses, leading to a fall in GDP and a loss in output (Barzani \& Maital, 2020). According to a study by McKinsey in February 2020, the demand contraction slowed down global economic growth by around 1.8-2.2\% (Barzani \& Maital, 2020).

\section{Biotech and Pharma Stock Behaviour}

In light of the stagflation recession, inflation in equity prices was apparent as investors borrowed at profoundly lowinterest rates with no other viable investment avenue besides equity. Biotech stocks which remained resilient despite the global economic recession caused by COVID-19, have, according to the numbers, outperformed the S\&P 500 index in 2020, the forerunners being the organizations involved actively in vaccine production and treatments (Kuchler \& Mooney, 2020).

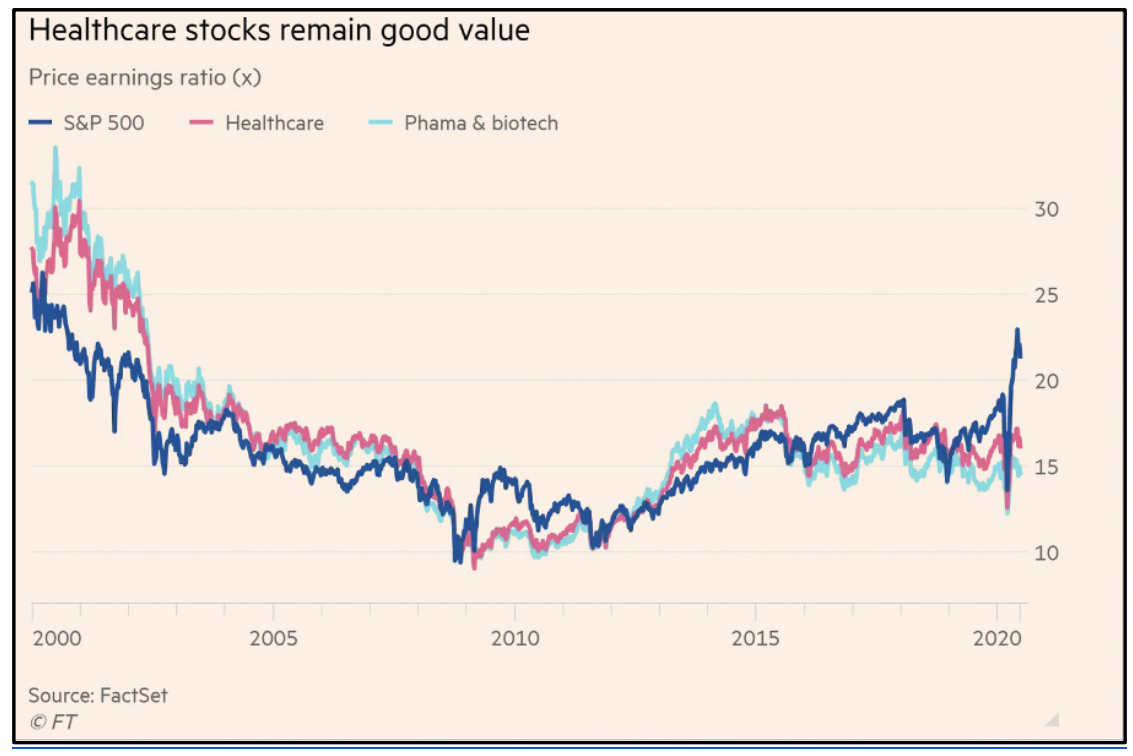

Fig 2. Healthcare stocks in comparison with S\&P 500.

This pattern is commonly noticed across global disease outbreaks. When SARS broke out in 2002, while equities in Asia began underperforming relative to the rest of the world, the domestic pharmaceutical industries in China gained 11\% due to anticipated demand for vaccinations (Morris, 2020). Similarly, the dismal quarter for most 
sectors reflective of the public's reception to the outbreak of the "swine flu" was, in fact, beneficial to the biotech and pharmaceutical industry with the growth of the market for vaccines (Steenhuysen, 2009). The three largest vaccine producers before COVID: GlaxoSmithKline, Merck, and Sanofi, are overtaken by fresh biopharmaceutical start-ups like Moderna and BioNTech. The prices of these company shares have been reflective of their immense success. Moderna has witnessed an $850 \%$ increase in share prices, and BioNTech's shares have risen $190 \%$ since the beginning of 2020 (Abboud \& Kuchler, 2021). The following stock prices will be analyzed during specific time-frames: one year before, one month before, one month after, and one year after emergency use authorization or vaccine approval, as well as implications of gaining publicity, staging clinical trials, etc.

\section{Gilead Sciences and its role in the COVID-19 pandemic}

Gilead Sciences Inc. (GILD), the biopharmaceutical company credited with the development of the first emergency food FDA approved COVID-19 treatment, Veklury (Remdesivir), saw its shares rise 18\% after their announcement on October 22nd, 2020 (Kuchler \& Mooney, 2020). During the H1N1 pandemic, market leaders at the time, such as GlaxoSmithKline Plc, Sanofi-Aventis SA, and AstraZeneca Plc, were reporting "windfall sales" of H1N1 flu vaccines (Steenhuysen, 2009). On the contrary, Gilead Sciences Inc's sales forecasts soared due to royalties collected on the drug Tamiflu (Pardo, Shukla, Chamarthi, \& Gupte, 2020). The drug administered as an injection had proven successful in treating SARS (2003) and MERS (2012), both categorized as coronaviruses, as well as a potential treatment for the Ebola outbreak (Jr., 2020).

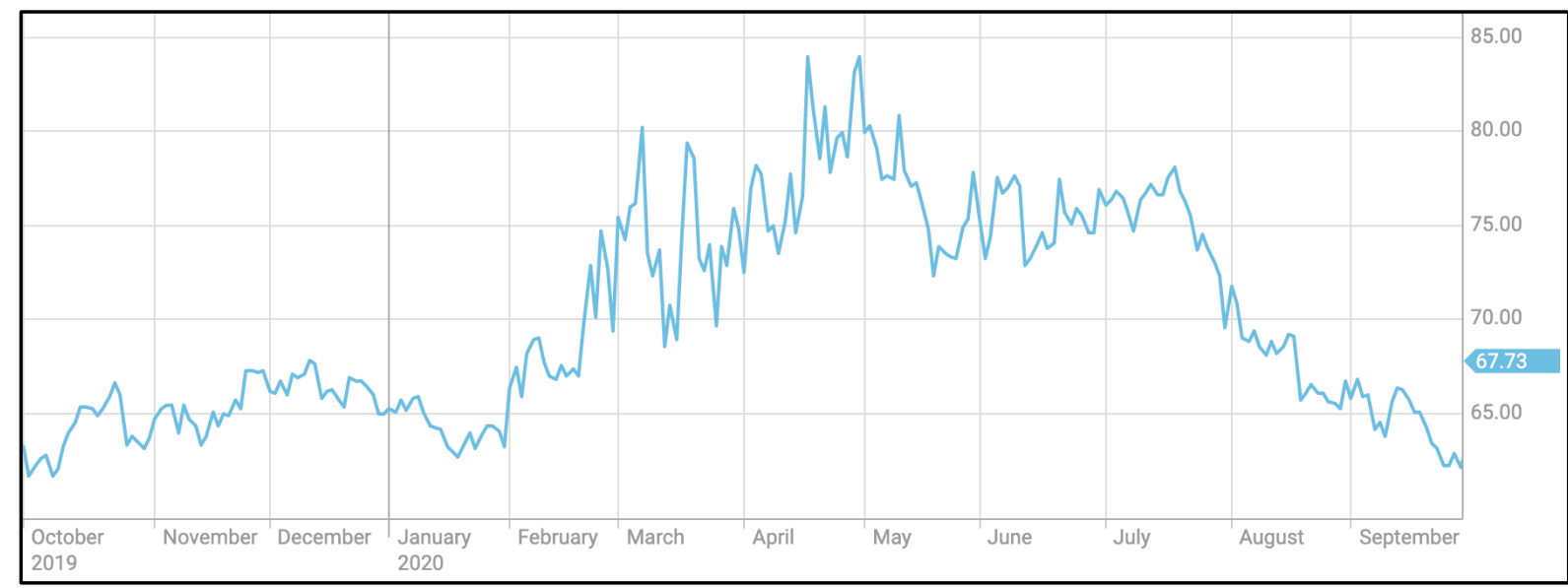

Fig 3a. GILD share price from October 2019 to October 2020.

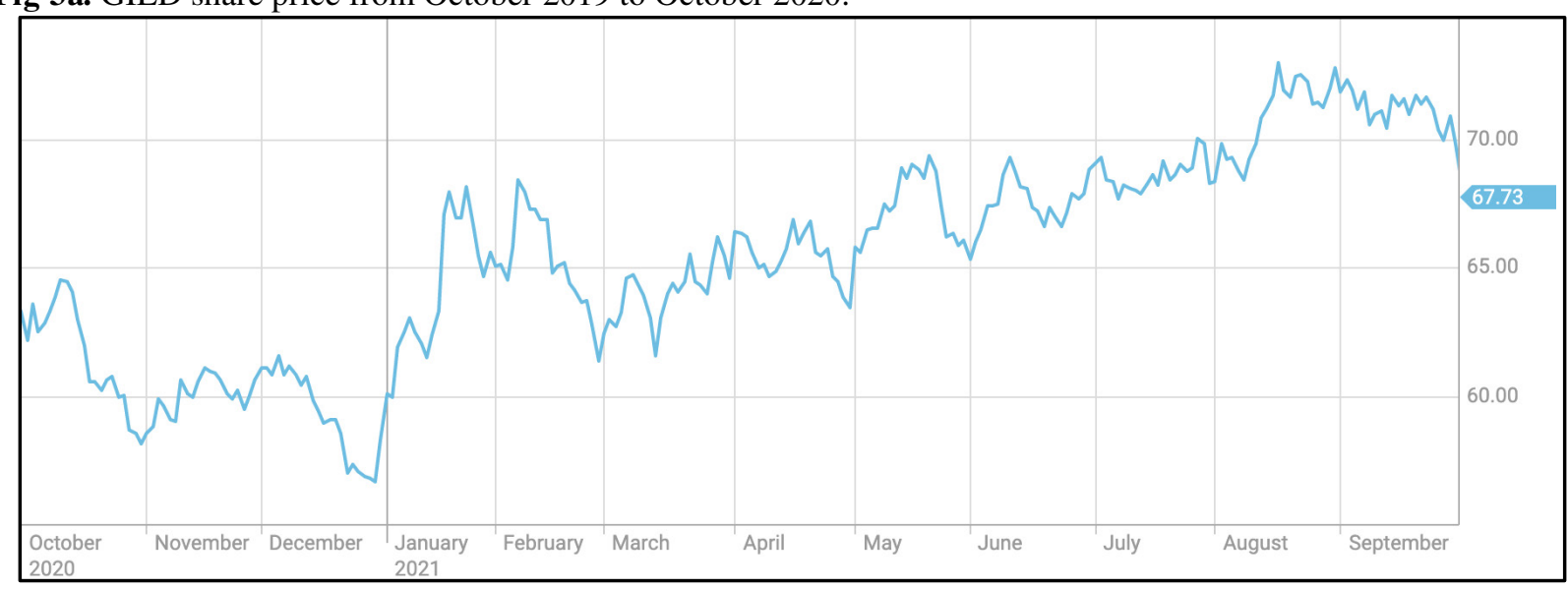

Fig 3b. GILD share price from October 2020 to October 2021. 
Gilead Sciences Inc began its research into Remdesivir, a "broad-spectrum antiviral drug" that displayed action against several virus families, as early as 2009 (Chong, 2020). In early October 2020, Gilead Sciences Inc signed a potential billion-dollar agreement with the EU to supply their antiviral drug as a treatment for COVID-19. Two weeks later, the FDA approved the drug for use against the pandemic in the United States (Cohen \& Kupferschmidt, 2020).

One year before Remdesivir approval, GILD shares shot up from lows of below $\$ 65$ in January 2020 to around $\$ 70$ by the end of March 2020, and this upward trend continued into April of the same year when shares hit \$84, a GILD all-time high (Trefis Team, 2021). Remdesivir was proven to decrease recovery time from 15 to 11 days in infected patients by a study published in the New England Journal of Medicine in May (Chong, 2020). However, in November, the World Health Organisation released a statement advising against using the drug for COVID-19, stating no measurable benefits in reducing mortality or recovery times. This announcement, along with the company's blockbuster drug Truvada losing its patent, its Hepatitis $\mathrm{C}$ portfolio witnessing a drop in sales, and its decision not to pursue regulatory approval for its arthritis drug, all culminated in a share price drop to $\$ 57$ September of 2020, one month before FDA approval (Trefis Team, 2021). One month after the announcement, in November of the same year, prices remained relatively stable at $\$ 60$. Starting from December 2020, two months later, share prices witnessed a sudden surge from $\$ 68$ in January 2021 to $\$ 75$ in late August, roughly a year post-approval.

\section{AstraZeneca - An Analysis}

AstraZeneca (AZN) earned its place as a market leader in the biotech industry during the H1N1 pandemic for its unique intranasal vaccine delivery. The publisher of an independent market research company, Kalorama, stated that even though the initial response to the Flu Mist was stunted, people grew more comfortable with the intranasal method of delivery (Manufacturing Chemist, 2010).

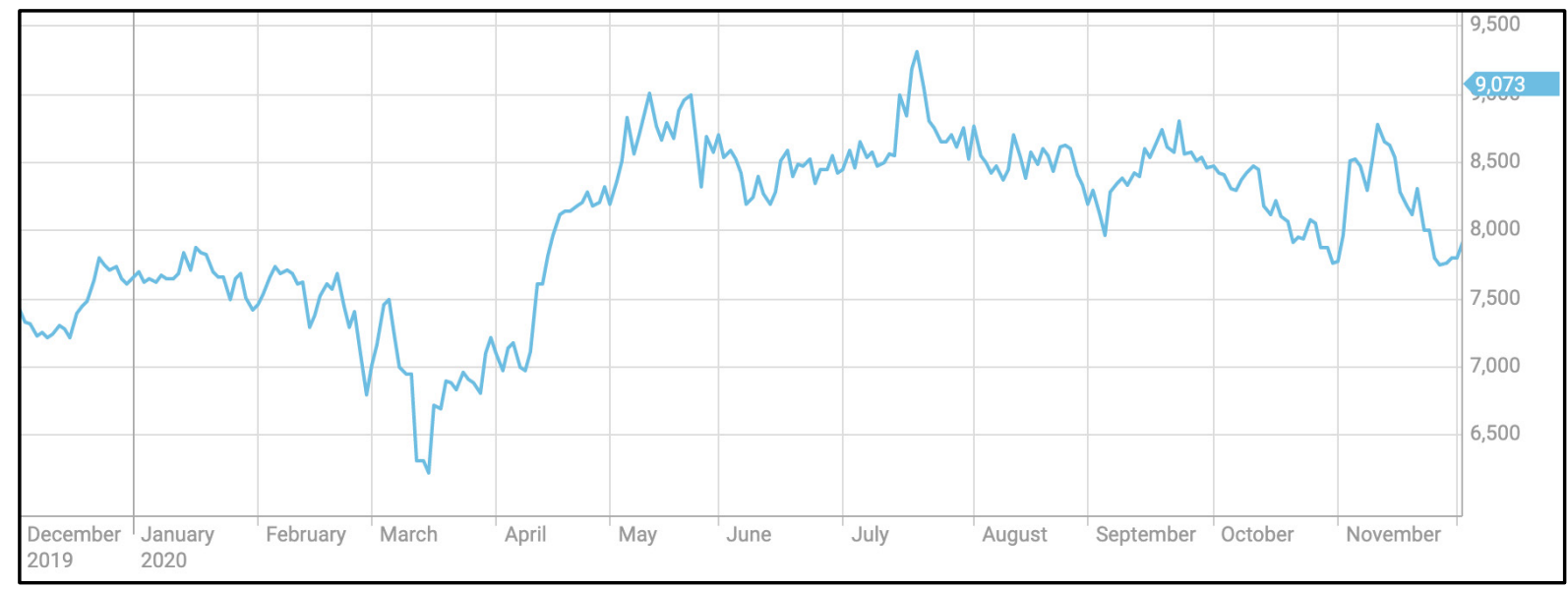

Fig 4a. AZN share price during December 2019 to December 2020. 


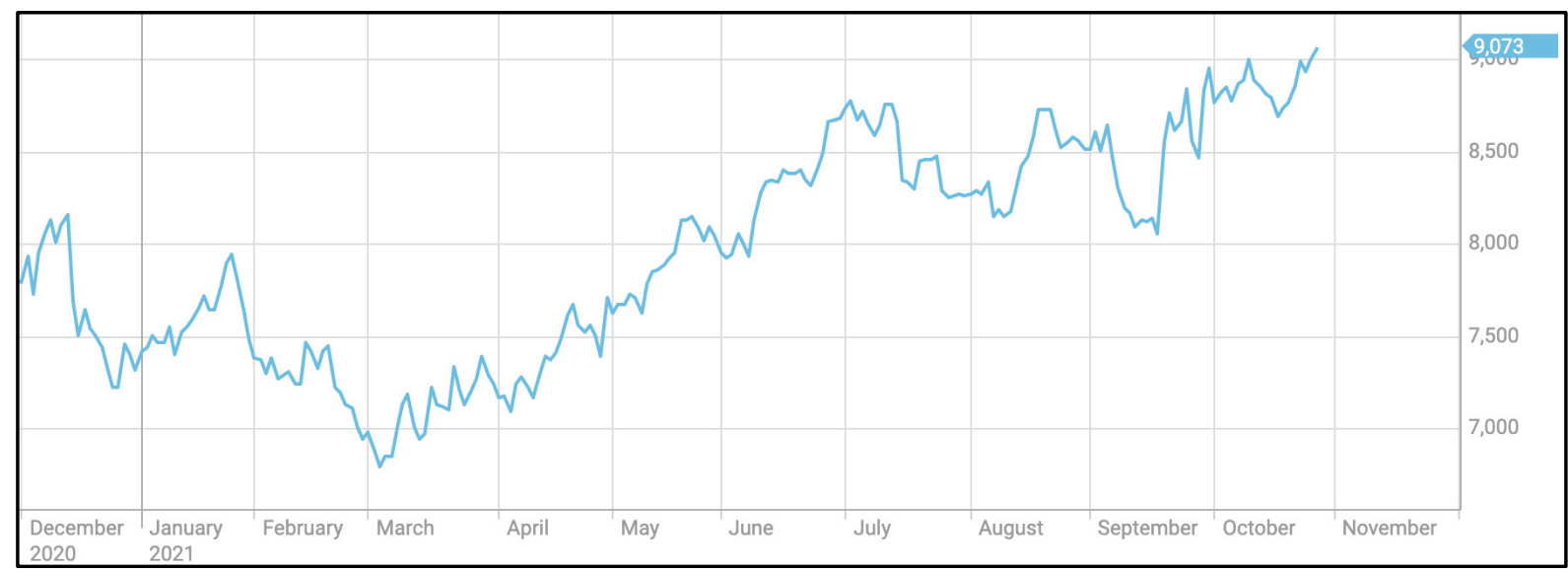

Fig 4b. AZN share price during December 2020 to October 2021.

Although its core business focuses primarily on the treatment of diseases in areas such as oncology, respiratory and autoimmunity, cardiovascular, and metabolic diseases, the British-Swedish company decided to enter the vaccine market during the COVID-19 pandemic by manufacturing and distributing the vaccine developed by Oxford University (Gross, Peel, \& Kuchler, 2021). While the vaccine hasn't received FDA approval, it was authorized by the British government for emergency use by December of 2020 (Zimmer \& Corum, 2021). The company has a production target of 2 billion doses to hit by the end of 2021 (Gardner, Pagliarulo, \& Fidler, 2021).

One year before British government authorization, in December of 2019, AZN share prices were approximately \$7400. The onslaught of the pandemic primarily caused the dip in March. In April 2020, AstraZeneca and Oxford University announced their landmark agreement for the COVID-19 vaccine (Kemp, 2020). Consequently, share prices shot up throughout April and May to reach $\$ 9000$ by the end of May. By November of 2020, one month before British government authorization, its price was $\$ 7500$ and trending downwards. One month after the announcement, prices increased to around $\$ 7925$.

However, more recent reports by the European Medicines Agency (EMA) have linked the AstraZeneca vaccine to a rare blood clotting condition called the Capillary Leak Syndrome (CLS) (Aripaka \& Burger, 2021). The company's shares fell 2.28\% to $\$ 6800$ on 11th March 2021, after Denmark, Norway, and Iceland announced their suspension of administering the vaccine as it underwent investigations for the CLS side effects (Steiner, 2021). A study carried out by the NIHR Health Protection Unit in Emergency Preparedness and Response reported only $17 \%$ of the public would prefer the AstraZeneca vaccine, if given a choice, as opposed to the $24 \%$ reported in March 2021 with a $10 \%$ increase in the number of people who believe the vaccine causes blood clotting (Ellyatt, 2021). Fortunately, shares have rebounded after the dip, mainly due to the excellent performance of other drugs in AstraZeneca's portfolio, including cancer drug Imfinzi which was clinically proven to boost liver cancer survival rates. Thus, share prices are $\$ 9000$ as of October 2021, a year after authorization.

\section{Moderna and the mRNA technology}

On 14th December 2020, when the first approved mRNA vaccine was administered in the United States, the world was unaware and skeptical of this experimental technology. However, when Moderna (MRNA), the American pharmaceutical company pioneering in mRNA vaccines, publicly announced its presence in 2013, it had already been operating in "stealth mode" since its launch in 2011 (Servick, 2020). By the time the viral outbreak of SARS-CoV-2 caused a global lockdown, Moderna had spent several years developing and refining their synthetic mRNA technology. Backed by years of clinical testing and fact-finding, researchers at Moderna downloaded the genetic sequence for the virus from Wuhan scientists. 
The idea behind Moderna stemmed from the possibility of re-engineering mRNA, or messenger ribonucleic acid, molecules that carry genetic information from the cell's nucleus to the ribosomes, into a "versatile set of drugs and vaccines" (Servick, 2020). The vaccine battles the COVID-19 virus by instructing the body's cells to create a defining feature of the virus - its "spike protein." Once the body's immune system recognizes the foreign particle as an intruder, it produces antibodies to prevent an infection (Isaacs-Thomas, 2021). In doing so, when confronted with the actual virus, the body recognizes the spike protein and attacks it (Corum \& Zimmer, 2021). Currently, Moderna is seeking approval to vaccinate teenagers from 12 - 17 years of age after a study revealed that the vaccine safely provided immunity against the virus in adolescents (Fontana, 2021). Since it began work on its coronavirus vaccine, the barrage of press releases documenting Moderna's efforts played a crucial role in the rise of its stock to more than triple its value, resulting in a $\$ 30$ billion market value company (Drucker \& Gelles, 2020).

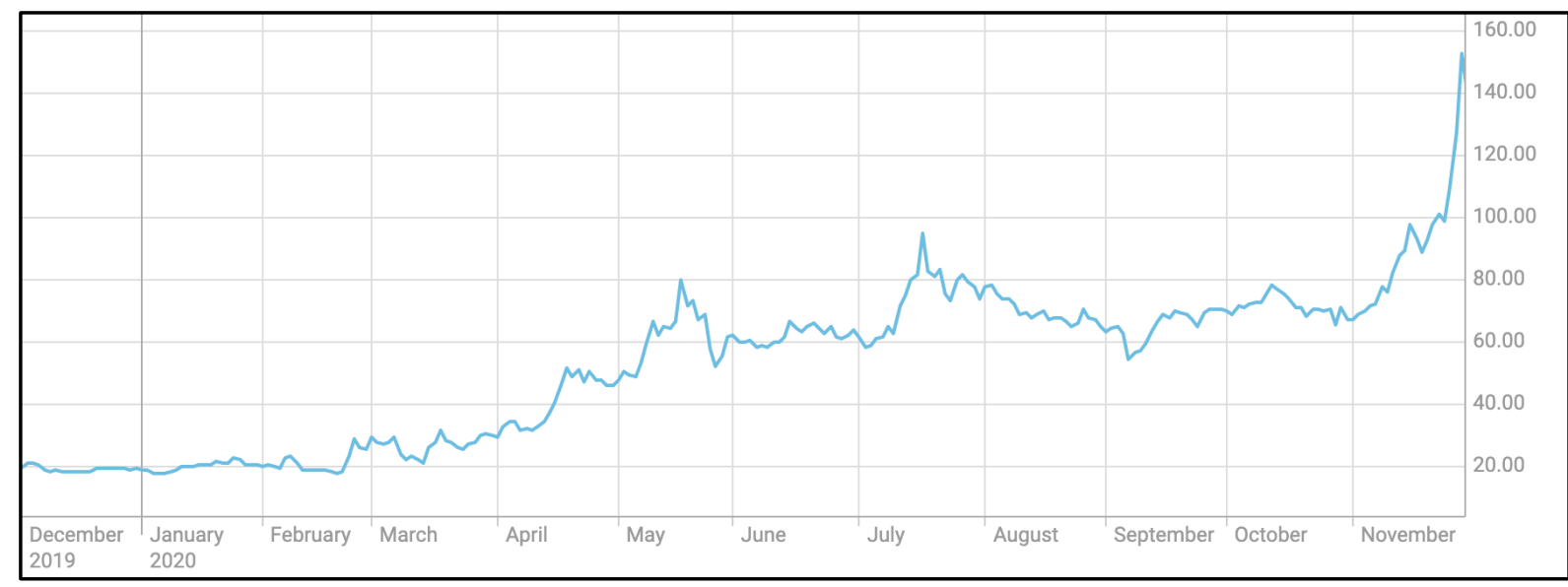

Fig 5a. MRNA share price during December 2019 to December 2020.

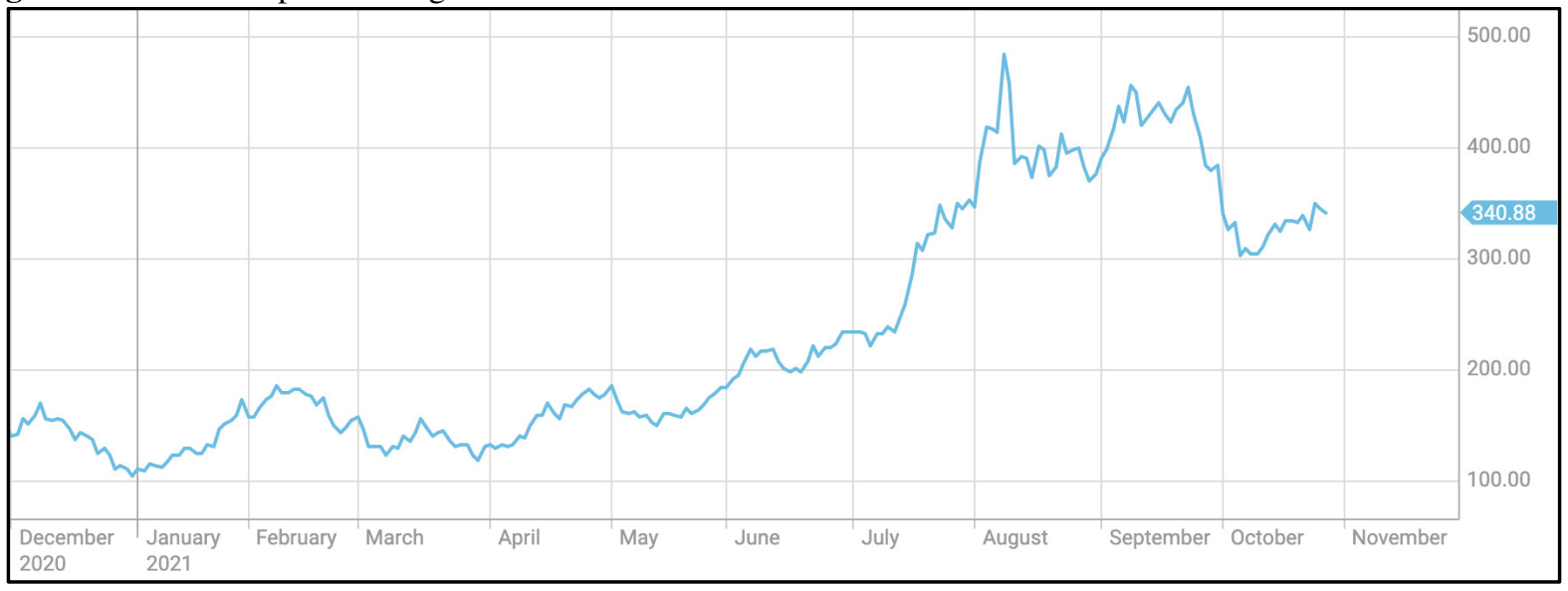

Fig 5b. MRNA share price during December 2020 to October 2021.

The Moderna vaccine was authorized for emergency use during December 2020 (Ledford, 2020). One year prior, in December of 2019, Moderna's share prices were relatively low at approximately \$20, which was expected as the company went public in December of 2018. By March 2020, they had started clinical trials for the COVID-19 vaccine (Thompson, 2021). Shares of Moderna have more than doubled since human trials began for the team's ground-breaking vaccine (Kuchler \& Mooney, 2020). Moderna's stock witnessed a 12\% surge in July 2020, after announcing the success of its vaccine trial on 45 patients, all of whom reported increased production of "neutralizing antibodies," higher than the numbers seen in patients who had recovered from COVID-19 (Jr., 2020). One month before authorization, in November 2020, share prices have already increased to $\$ 95$. One month after authorization, stock prices started growing exponentially, reaching $\$ 171$ by the end of January 2020 , and continued rising to a peak 
of $\$ 485$ by August 2021, roughly a year after the EUA (emergency use authorization). The company plans to hit 800 million to a billion doses by 2021 and aims to roll out up to 3 billion doses by the end of 2022 (Gardner, Pagliarulo, \& Fidler, 2021).

\section{Understanding the Pfizer Stock}

Keeping with the trend of resilient biotechnology stocks, Pfizer (PFIZ), a prominent pharmaceutical industry player, signed a deal with BioNTech to develop mRNA vaccines similar to that of Moderna's (Armstrong, 2020). On 9th of November in 2020, it announced that its vaccine had a more than 90\% efficiency rate (Wee, Corum, \& Zimmer, 2021). That same day, the company saw its shares rise by 15\% (Langreth, Kresge, \& Griffin, 2020). In December 2020, after releasing its analysis of the vaccine, which determined it has a 95\% efficacy rate, the FDA approved the Pfizer-BioNTech vaccine as the first vaccine authorized for emergency use (Wee, Corum, \& Zimmer, 2021).

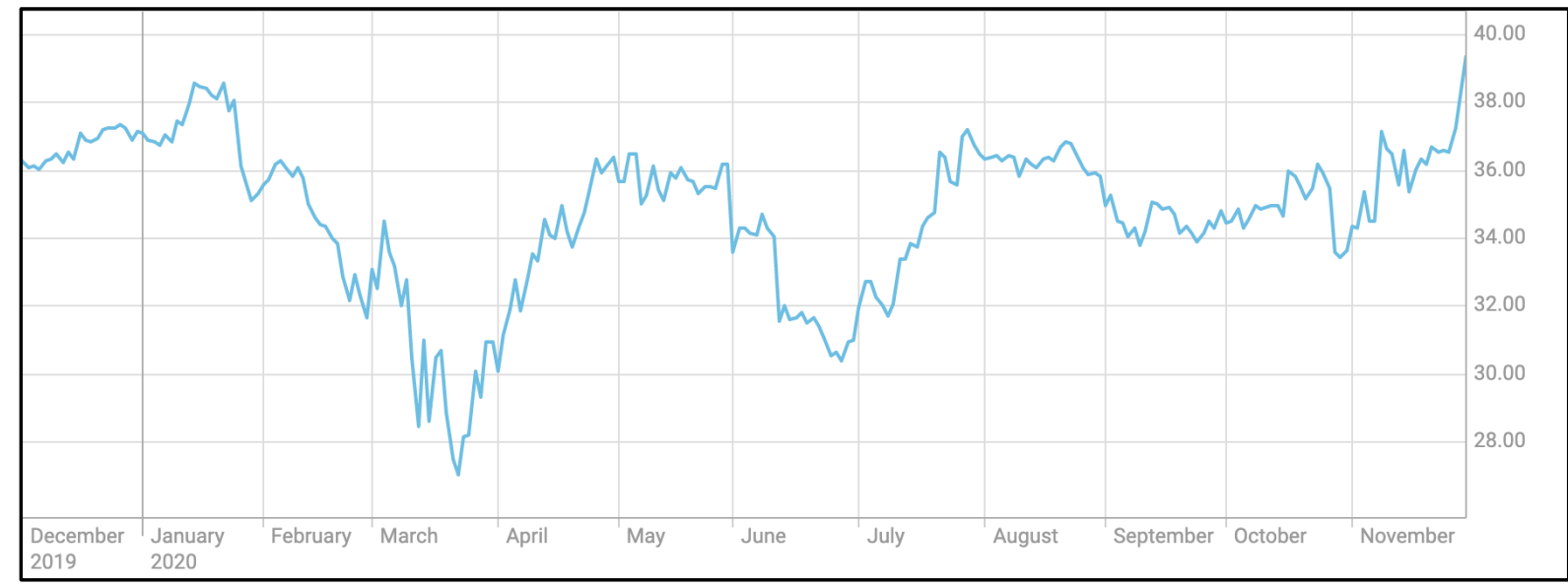

Fig 6a. PFE share price during December 2019 to December 2020.

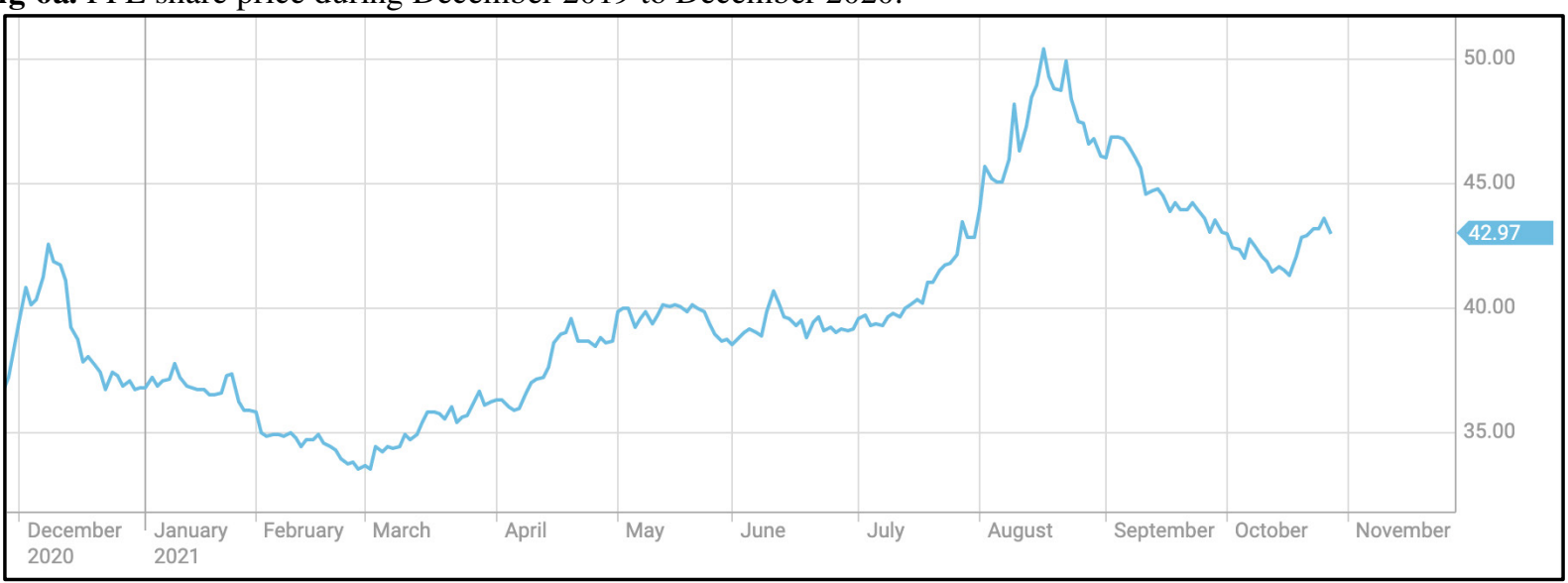

Fig 6b. PFE share price during December 2020 to October 2021.

One year before the FDA's emergency use authorization, PFE share price was around \$36 and experienced heavy fluctuations throughout 2020. The share's price dip in March 2020 was due to the pandemic (Speights, 2021). Fortunately, PFIZ stocks rebounded relatively quickly that by the end of November 2020, one month before the PfizerBioNTech vaccine EUA announcement, its share price was again at $\$ 36$. Due to speculations of the first vaccine authorization, stock prices increased to $\$ 43$ by mid-December. However, one month after EUA, share prices fell to 
$\$ 37$ and continued to decrease until the end of February the same year, after which prices steadily increased. Prices peaked and reached an all-time high of $\$ 50$ in mid-August 2021, roughly a year after authorization.

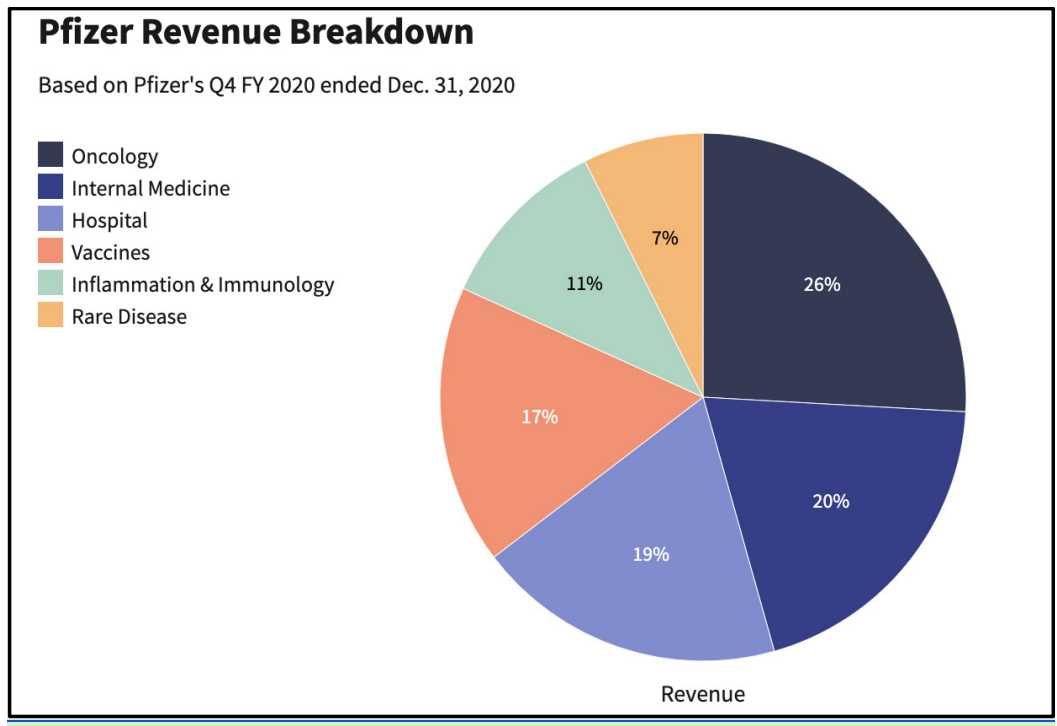

Fig 7. Breakdown of Pfizer's revenue sources.

More than $60 \%$ of the total market estimate for vaccines for 2021 and 2022 is accounted for by Pfizer-BioNTech and Moderna (Terry, 2021), and the former's aims to achieve a production target of 2.5 billion doses in 2021 and 3 billion in 2022 (Gardner, Pagliarulo, \& Fidler, 2021). Pfizer also plans to utilize the ease of editing mRNA by developing vaccines against seasonal influenza that can mutate constantly. In the first quarter of 2021, Pfizer sales grew $45 \%$ to $\$ 14.58 \mathrm{~B}$, and adjusted earnings were 93 cents per share, both figures beating analyst forecast consensus (Gatlin, 2021). Although the vaccine brought in $\$ 3.5$ billion or a quarter of Pfizer's annual revenue, the vaccine is not its largest source of revenue (Robbins \& Goodman, 2021). The company's internal medicine department develops therapeutics for cardiovascular conditions, liver diseases, diabetes, and obesity disorders and accounts for $20 \%$ of its revenues. Oncology, bringing in around 26\% of Pfizer's total revenue, is its largest revenue source (Johnston, 2021).

New vaccines under development

With market leaders paving the way for other biopharma companies to enter into the vaccine market, several new vaccines are currently in the pipeline under a combined Phase 1 and Phase 2 development stage.

After initial results were determined unsuccessful, the South Korean firm Genexine developed a modified version of their vaccine candidate for COVID-19 treatment and registered for Phase 1/2 trials (Wee, Corum, \& Zimmer, 2021). Kalbe Farma, an Indonesian pharmaceutical company, has agreed to buy 10 million doses of GX-19N (Genexine, Inc., 2021) to distribute among South Asian countries if proven safe and successful (Hyun-tai, 2021).

French pharmaceutical firm Sanofi (SNY) developed its second vaccine, an mRNA candidate in partnership with Translate Bio, which has entered the Phase $1 / 2$ trial stage (Wee, Corum, \& Zimmer, 2021). Its first candidate in conjunction with GlaxoSmithKline had an initial production target of 1 billion doses by mid-2021. However, due to disappointing results from its Phase 1 trials, the company decided to re-engineer its vaccine, pushing back availability to the fourth quarter of 2021 (Gardner, Pagliarulo, \& Fidler, 2021).

Although its core business revolves around experimental cancer treatments, the New Jersey-based pharma OncoSec Immunotherapies (ONCS) decided to adapt its technology to develop a COVID-19 vaccine, CORVax12, which began Phase 1 trials in late January (Wee, Corum, \& Zimmer, 2021). Closely following a similar timeline is Canada's Providence Therapeutics (PTCT), which announced the safety and efficacy of their mRNA PTX-COVID19B (Providence Therapeutics Holdings Inc, 2021) vaccine in May 2021 (Wee, Corum, \& Zimmer, 2021). They have 
entered into a licensing agreement with Biological E in India to roll out 30 million doses in 2021 and a target of 1 billion in 2022 (Reuters, 2021).

Unlike most other competitors scrambling to develop injections, San Francisco's Vaxart (VXRT) specializes in oral vaccines (Wee, Corum, \& Zimmer, 2021). Vaxart began 2020 with share prices as low as 35 cents and provided stock options to Armistice Capital, a New York-based hedge fund that acquired two-thirds of the company's shares, to 21 million more shares in the future for not more than 30 cents. As investors began picking up on the company and its potential for large profits, Vaxart's share price increased ten-fold to \$3.66 by April 2020 (Drucker \& Gelles, 2020).

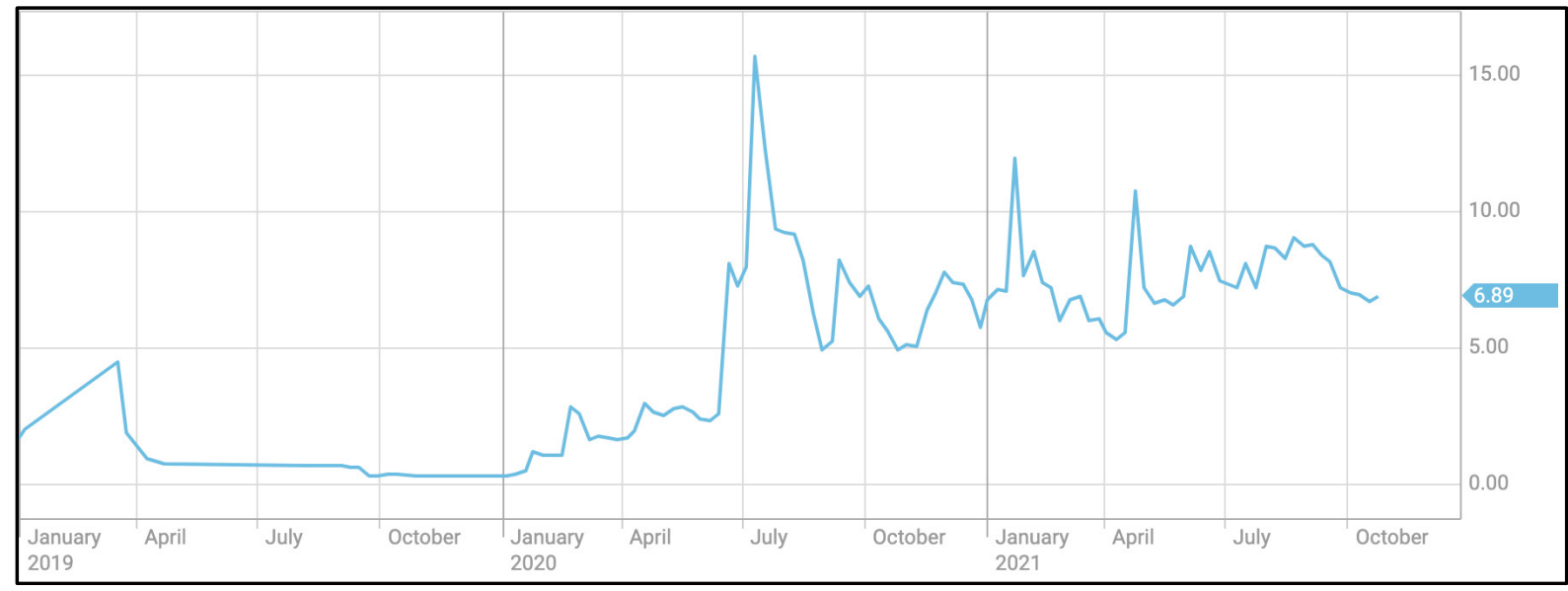

Fig 8. Vaxart share price - January 2019 to October 2021

The biggest gain came from the company's decision to contractually allow Armistice to buy the 21 million shares outright without breaking it down into smaller batches and announcing their new CEO Andrei "Andy" Floroiu, a former colleague of the founder of Armistice. The following day the company announced a press release that caused share prices to double, hitting \$14, a record high (Drucker \& Gelles, 2020). Although Vaxart's press release was titled "Vaxart's Covid-19 Vaccine Selected for the U.S. Government's Operation Warp Speed", the truth was slightly different. The company did not receive funding from Warp Speed to mass-produce vaccine tablets, as the release stated. Instead, Vaxart's candidate was chosen to "participate in preliminary U.S. government studies to determine potential areas for possible Operation Warp Speed partnership and support," said Michael R. Caputo, assistant secretary for public affairs at the U.S. Department of Health and Human Services. This misleading press release title seemed to have been an attempt on the company's part to bolster stock prices. A combination of retail investors with high short interest following the GameStop short squeeze investing in small stocks, and the anticipation of Phase 1 results of its tablet vaccine candidate led Vaxart to witness a 3,600\% rise in stock price in June 2020 (Trefis Team, 2021). Within days, Armistice bought and sold almost all its shares of Vaxart, making extensive profits of around \$200 million (Gelles, 2020). The recent results from the Phase 1 testing of their tablets on hamsters reported statistically significant results of antibody induction and protection against lung weight gain (VAXART, 2020), a symptom of the coronavirus disease (Wee, Corum, \& Zimmer, 2021).

\section{Conclusion}

As per World Bank reports, epidemics result in lasting impacts on global economies through 2 primary channels. The first is either a temporary or permanent fall in labor supply due to high mortality rates during an outbreak alongside increased contingencies to minimize the spread; the second is an impact on labor force participation rates arising from behavioural changes caused by the crisis (Lee \& Cho, 2016). Both cases are consistent across all pandemics discussed in this paper, along with other sectors affected; such as travel and tourism, financial industries, and hospitality. 
The onset of COVID-19 brought several existing and new vaccine makers to the forefront of the battle against the pandemic. At first glance, vaccine release seems to generally influence stock prices of companies, with companies like Gilead, AstraZeneca, Moderna whose stocks increased to various degrees a month or two after the authorization announcements. However, with companies like Pfizer, where the primary revenue source is unrelated to vaccine product sales, stock prices haven't been dramatically volatile; as shares remained relatively unchanged at \$35 from November 2020 to March 2021 (Bary, 2021). Thus, a more specific, generalizable trend that is consistent is one with an exponential rise in stock prices following positive news related to COVID-19 vaccine approvals and trials. In the UK, Tiziana, a UK stock; Genedrive, a life sciences company; and BioNTech, the German giant, provide a few examples of a large number of biotechnology stocks that rose due to news regarding partnerships, potential treatments for highly susceptible patients, and production testing (Rojas, 2020). However, the success of vaccines from a public-health perspective may not always be reflected in the performance of share prices of the companies involved (Bowler, 2021).

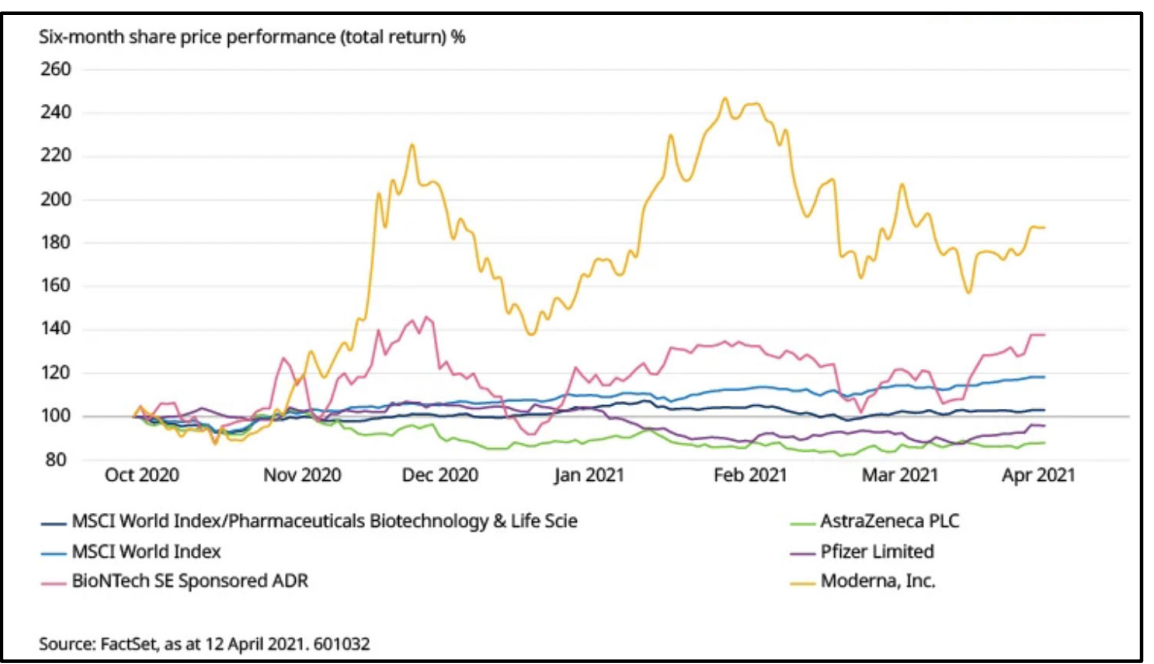

Fig 9. Share price performance - October 2020 to April 2021

The figure above is reflective of the less volatile trends for larger market players such as Pfizer and AstraZeneca, compared to companies like Moderna and Vaxart. While distribution and supply problems or health concerns may be a potential explanation for the share price fluctuation, a driving factor that influences the biopharma stock trends is the technology powering these vaccines. The mRNA technology on which Moderna and BioNTech's vaccines were built upon has been the subject of years of research and uncertainty for several pharmaceutical players. As such, share price gains of Moderna and BioNTech might be reflective of the future potential of mRNA technology in fields besides COVID-19 (Bowler, 2021).

Success rates during the clinical trials of new vaccines developed with new technologies also play a crucial role in the behaviour of their respective share prices. For example, the share price of CurVac, a new German developer, dropped $50 \%$ on 17 th June 2021, after the public release of their clinical trials which stated that the vaccine was only $47 \%$ effective (Burger, 2021).

While the competitors mentioned in this paper are not exhaustive, they provide a holistic view of the current stock market conditions and a summary of stock trends for biotechnology companies. Given the current global economic and financial conditions of the COVID-19 pandemic, the biotech industry is teeming with new developments and technologies. Despite being high risk, both large pharmaceutical companies with years of experience and smaller start-ups with growth potential prove to be a goldmine for investors. 


\section{Acknowledgements}

I would like to express great appreciation to my advisor Mrs. Meredith Haskins and mentor Jacob Stern for their kind support and helpful feedback. This paper would not have been written to its current caliber without their guidance.

\section{References}

Abboud, L., \& Kuchler, H. (2021, February 16). Why the three biggest vaccine makers failed on Covid-19. Retrieved from Financial Times: https://www.ft.com/content/657b123a-78ba-4fba-b18e-23c07e313331

Agrawal, G., Ahlawat, H., \& Dewhurst, M. (2021, January 8). Biopharma 2020: A landmark year and a reset for the future. Retrieved from McKinsey \& Company: https://www.mckinsey.com/industries/pharmaceuticals-andmedical-products/our-insights/biopharma-2020-a-landmark-year-and-a-reset-for-the-future\#

Aripaka, P., \& Burger, L. (2021, June 12). EU adds another rare blood condition as side effect of AstraZeneca shot. Retrieved from Reuters: https://www.reuters.com/business/healthcare-pharmaceuticals/eu-advises-againstastrazeneca-shot-people-with-rare-blood-condition-2021-06-11/

Armstrong, D. (2020, December 23). The World's Most Loathed Industry Gave Us a Vaccine in Record Time. Retrieved from Bloomberg Businessweek: https://www.bloomberg.com/news/features/2020-12-23/covid-vaccine-how-big-pharma-saved-the-world-in-2020

Baldo, V., Bertoncello, C., \& Cocchio, S. (2016). The new pandemic influenza A/(H1N1)pdm09 virus: is it really "new"? The Journal of Preventive Medicine and Hygiene.

Barua, A. (2020, May 20). Economic impact of epidemics and pandemics in Asia since 2000. Retrieved from Deloitte Insights: https://www2.deloitte.com/us/en/insights/economy/asia-pacific/economic-impact-of-epidemics-and-pandemics.html

Bary, A. (2021, March 15). Big Pharma Battled the Pandemic. The Stocks Are Cheap. Retrieved from Barron's: https://www.barrons.com/articles/big-pharma-battled-the-pandemic-the-stocks-are-cheap-51615595798

Barzani, E., \& Maital, P. S. (2020). The Global Economic Impact of COVID-19: A Summary of Research. Retrieved from Samuel Neaman Institute for National Policy Research: https://www.neaman.org.il/EN/TheGlobal-Economic-Impact-of-COVID-19-A-Summary-of-Research

Bowler, J. (2021, April 21). Who's making money from Covid-19 vaccines? Retrieved from Schroders: https://www.schroders.com/en/il/professional-investor/insights/markets/whos-making-money-from-covid-19vaccines/

Burger, Ludwig. "CureVac Fails in Pivotal COVID-19 Vaccine Trial with 47\% EFFICACY." Reuters, Thomson Reuters, 17 June 2021, www.reuters.com/business/healthcare-pharmaceuticals/curevacs-covid-19-vaccinemisses-efficacy-goal-mass-trial-2021-06-16/ 
CDC. (n.d.). 2009 H1N1 Pandemic (H1N1pdm09 virus). Retrieved from Centers for Disease Control and Prevention: https://www.cdc.gov/flu/pandemic-resources/2009-h1n1-pandemic.html?web=1\&wdLOR=c744FE0F61589-0944-A463-1B0932CD549B

CDC, NCIRD. (2019, May 8). 2009 H1N1 Pandemic Timeline. Retrieved from Centers for Disease Control and Prevention: https:/www.cdc.gov/flu/pandemic-resources/2009-pandemic-timeline.html

Cherry, J. D., \& Krogstad, P. (2004). SARS: The First Pandemic of the 21st Century. Paediatric Research. Retrieved from Nature: https://www.nature.com/articles/pr2004163

Chong, C. (2020, June 11). Coronavirus: Research that led to antiviral drug started in 2009. Retrieved from The Straits Times: https://www.straitstimes.com/singapore/research-that-led-to-antiviral-drug-started-in-2009

Cohen, J., \& Kupferschmidt, K. (2020, October 28). The 'very, very bad look' of remdesivir, the first FDA-approved COVID-19 drug. Retrieved from Science: https://www.sciencemag.org/news/2020/10/very-very-badlook-remdesivir-first-fda-approved-covid-19-drug

Coniam, M. (2021, April 30). Stocks That Soared on Covid Treatments Are Coming Back to Earth By Morwenna Coniam 30 April 2021, 12:00 GMT+8 Vaccine rollout has undermined enthusiasm for drug development Some firms have abandoned efforts to create Covid treatments LISTEN TO ARTICLE 6. Retrieved from Bloomberg: https:/www.bloomberg.com/news/articles/2021-04-30/stocks-that-soared-on-covid-treatmentsare-coming-back-to-earth

Corum, J., \& Zimmer, C. (2021, May 7). How Moderna’s Vaccine Works. Retrieved from The New York Times: https://www.nytimes.com/interactive/2020/health/moderna-covid-19-vaccine.html

Donald, H., \& Yiping, H. (2004). The Impact of SARS on Asian Economies . Retrieved from Asian Economic Papers: https://econpapers.repec.org/article/tprasiaec/v_3a3_3ay_3a2004_3ai_3a1_3ap_3a102-112.htm

Drucker, J., \& Gelles, D. (2020, July 25). Corporate Insiders Pocket \$1 Billion in Rush for Coronavirus Vaccine. Retrieved from The New York Times: https://www.nytimes.com/2020/07/25/business/coronavirus-vaccineprofits-vaxart.html

Ellyatt, H. (2021, April 27). Public demand for AstraZeneca vaccine falls in Britain after blood clot scares. Retrieved from CNBC: https://www.cnbc.com/2021/04/27/public-demand-for-astrazeneca-vaccine-falls-afterblood-clot-scares.html

Fontana, F. (2021, June 11). Moderna, GameStop, Amazon.com: Stocks That Defined the Week. Retrieved from The Wall Street Journal: https:/www.wsj.com/articles/moderna-gamestop-amazon-com-stocks-that-definedthe-week-11623451394? mod=searchresults_pos1\&page=1

Forum, W. E. (2020, February 19). 3 charts that compare coronavirus to previous outbreaks . Retrieved from World Economic Forum: https://www.weforum.org/agenda/2020/02/comparing-outbreaks-coronavirus-mers-sarshealth-epidemic/ 
Gardner, J., Pagliarulo, N., \& Fidler, B. (2021, June 1). Coronavirus vaccines are rolling out quickly. Here's where the pipeline stands. Retrieved from BIOPHARMADIVE: https://www.biopharmadive.com/news/coronavirusvaccine-pipeline-types/579122/

Gatlin, A. (2021, August 6). Is Pfizer Stock A Buy As It Eyes \$26 Billion In Full-Year Covid Vaccine Sales? Retrieved from Investor's Business Daily: https://www.investors.com/news/technology/pfizer-stock-buy-now/

Gelles, D. (2020, October 15). U.S. Investigates Vaxart's Claims Related to Covid-19 Vaccine. Retrieved from The New York Times: https://www.nytimes.com/2020/10/15/business/vaxart-covid-coronavirus-vaccine.html

Genexine, Inc. (2021). Safety and Immunogenicity Study of GX-19N, a COVID-19 Preventive DNA Vaccine in Healthy Adults. ClinicalTrials.gov.

Grandview Research. (2021). Biotechnology Market Size, Share \& Trends Analysis Report By Technology (DNA Sequencing, Nanobiotechnology), By Application (Health, Bioinformatics), By Region, And Segment Forecasts, 2021 - 2028. Retrieved from https:/www.grandviewresearch.com/industry-analysis/biotechnologymarket/methodology

Gross, A., Peel, M., \& Kuchler, H. (2021, May 29). Does the AstraZeneca vaccine have a future? Retrieved from Financial Times: https://www.ft.com/content/2bae4886-78e5-4586-aa6f-2d3154e6d936

Hyun-tai, S. (2021, April 27). Genexine to supply Covid-19 vaccine candidate to Indonesia. Retrieved from Korea Biomedical Review: https://www.koreabiomed.com/news/articleView.html?idxno=11024

Isaacs-Thomas, I. (2021, April 2). The powerful technology behind the Pfizer and Moderna vaccines. Retrieved from PBS News Hour: https://www.pbs.org/newshour/health/the-powerful-technology-behind-the-pfizer-andmoderna-vaccines

Johnston, M. (2021, May 19). How Pfizer Makes Money. Retrieved from Investopedia: https://www.investopedia.com/articles/insights/080816/pfizer-7-secrets-you-didnt-know-pfe.asp

Jr., B. L. (2020, April 17). Biotech stocks surge as people are 'hungry' for good news on the coronavirus. Retrieved from CNBC: https://www.cnbc.com/2020/04/17/biotech-stocks-surge-as-people-are-hungry-for-good-newson-coronavirus.html

Kemp, Adrian. “AstraZeneca and Oxford University Announce Landmark Agreement for COVID-19 Vaccine.” (30 Apr. 2020). Retrieved from AstraZeneca: https://www.astrazeneca.com/media-centre/press-releases/2020/astrazeneca-and-oxford-university-announce-landmark-agreement-for-covid-19-vaccine.html.

Kim, Y.-W., Yoon, S.-J., \& Oh, I.-H. (2013). The economic burden of the 2009 pandemic H1N1 influenza in Korea. Scand J Infect Dis.

Kuchler, H., \& Mooney, A. (2020, July 6). Pharma industry seizes on pandemic as a shot at redemption. Retrieved from Financial Times: https:/www.ft.com/content/de90c59e-3cfb-43c4-8d30-d13dbe3962ae 
Langreth, R., Kresge, N., \& Griffin, R. (2020, November 9). Pfizer Soars as Vaccine Prevents 90\% of Covid Cases in Study. Retrieved from Bloomberg: https:/www.bloomberg.com/news/articles/2020-11-09/pfizer-s-covidvaccine-prevents-90-of-infections-in-large-study

Ledford, Heidi. "Moderna COVID Vaccine Becomes Second to Get Us Authorization." (2020, December 18). Nature News. Retrieved from Nature Publishing Group: https://www.nature.com/articles/d41586-020-03593-7.

LeDuc, J. W., \& Barry, A. M. (2004). SARS, the First Pandemic of the 21st Century. Emerging Infectious Diseases. Retrieved from ncbi: https://www.ncbi.nlm.nih.gov/pmc/articles/PMC3329048/

Lee, A., \& Cho, J. (2016). The impact of epidemics on labor market: identifying victims of the Middle East Respiratory Syndrome in the Korean labor market. International journal for equity in health. Retrieved from International Journal from Equity in Health: https://equityhealthj.biomedcentral.com/articles/10.1186/s12939-0160483-9

Manufacturing Chemist. (2010, May 11). Pharma companies earned US\$3.3bn on H1N1 vaccine. Retrieved from Manufacturing Chemist: https://manufacturingchemist.com/news/article_page/Pharma_companies_earned_US33bn_on_H1N1_vaccine/50607

Morris, D. (2020, February 27). Coronavirus - Lessons from SARS for investors. Retrieved from Investors' Corner: https://investors-corner.bnpparibas-am.com/investing/coronavirus-lessons-from-sars-for-investors/

Padhy, I., Song, J., \& Mahapatra, A. (2020, May) Role of Biotechnology in Pharmaceutical Research: A Comprehensive Review. Retrieved from ResearchGate: www.researchgate.net/publication/341407455_ROLE_OF_BIOTECHNOLOGY_IN_PHARMACEUTICAL_RESEARCH_A_COMPREHENSIVE_REVIEW.

Pardo, J., Shukla, A. M., Chamarthi, G., \& Gupte, A. (2020). The journey of remdesivir: from Ebola to COVID-19. Drugs in Context.

Providence Therapeutics Holdings Inc. . (2021, February 21). PTX-COVID19-B, an mRNA Humoral Vaccine, is Intended for Prevention of COVID-19 in a General Population. This Study is Designed to Evaluate Safety, Tolerability, and Immunogenicity of PTX-COVID19-B Vaccine in Healthy Seronegative Adults Aged 18-64. Retrieved from ClinicalTrials.gov: https:/clinicaltrials.gov/ct2/show/NCT04765436

Reuters. (2021, June 1). India's Biological E. to make Providence Therapeutics' mRNA COVID-19 vaccine. Retrieved from Reuters: https://www.reuters.com/business/healthcare-pharmaceuticals/indias-biological-emake-providence-therapeutics-mrna-covid-19-vaccine-2021-06-01/

Robbins, R., \& Goodman, P. S. (2021, May 5). Pfizer Reaps Hundreds of Millions in Profits From Covid Vaccine. Retrieved from https:/www.nytimes.com/2021/05/04/business/pfizer-covid-vaccine-profits.html

Rojas, C. D. (2020, April 20). How Has Coronavirus Affected Europe's Biotech Stocks? Retrieved from labiotech.eu: https://www.labiotech.eu/in-depth/biotech-stock-coronavirus/ 
Servick, K. (2020, March 25). This mysterious \$2 billion biotech is revealing the secrets behind its new drugs and vaccines. Retrieved from Science: https://www.sciencemag.org/news/2017/02/mysterious-2-billion-biotechrevealing-secrets-behind-its-new-drugs-and-vaccines

Sharma, S., \& Saiyed, T. (2021, April 23). Role of Biotechnology in India's Fight Against the COVID-19 Pandemic. Retrieved from Carnegie India: https://carnegieindia.org/2021/04/23/role-of-biotechnology-in-india-sfight-against-covid-19-pandemic-event-7633

Smith, R. D., \& Keogh-Brown, M. R. (2008). The economic impact of SARS: How does the reality match the predictions? Elsevier Public Health Emergency Collection. Retrieved from ncbi: https://www.ncbi.nlm.nih.gov/pmc/articles/PMC7114672/

Smith, R. D., \& Keogh-Brown, M. R. (2013, July 4). Macroeconomic impact of a mild influenza pandemic and associated policies in Thailand, South Africa and Uganda: a computable general equilibrium analysis. Influenza Other Respir Viruses, 7(6). Retrieved from researchgate: https://www.researchgate.net/publication/245026594_Macroeconomic_impact_of_a_mild_influenza_pandemic_and_associated_policies_in_Thailand_South_Africa_and_Uganda_A_computable_general_equilibrium_analysis

Speights, Keith. "Why Pfizer Was a Surprising Loser in 2020 but Could Win Big Time in 2021." (8 Jan. 2021) The Motley Fool. Retrieved from The Motley Fool: https:/www.fool.com/investing/2021/01/08/why-pfizer-wasa-surprising-loser-in-2020-but-coul/.

Steenhuysen, J. (2009, October 24). Companies reap the swine flu windfall. Retrieved from Reuters: https://www.reuters.com/article/us-flu-companies-analysis-idUSTRE59M3TZ20091023

Steiner, R. (2021, March 11). AstraZeneca Shares Fall as Denmark Pauses Shots of Its Covid-19 Vaccine Following Blood Clots. Retrieved from Barron's: https://www.barrons.com/articles/astrazeneca-shares-fall-as-denmarkpauses-shots-of-its-covid-19-vaccine-following-blood-clots-51615472047

Terry, M. (2021, May 26). UPDATED Comparing COVID-19 Vaccines: Timelines, Types and Prices. Retrieved from BioSpace: https://www.biospace.com/article/comparing-covid-19-vaccines-pfizer-biontech-modernaastrazeneca-oxford-j-and-j-russia-s-sputnik-v/.

Thompson, D. (2021, March 29). How mRNA Technology Could Change the World. Retrieved from The Atlantic: https://www.theatlantic.com/ideas/archive/2021/03/how-mrna-technology-could-change-world/618431/

Trefis Team. (2021, January 25). Should You Buy Johnson \& Johnson Stock At \$160? Retrieved from Forbes: https:/www.forbes.com/sites/greatspeculations/2021/01/25/should-you-buy-johnson--johnson-stock-at$160 /$ ? sh=5fa229b $17 \mathrm{~d} 75$

Trefis Team. (2021, March 1). Is Vaxart Stock Set To Decline Further? Retrieved from Forbes: https://www.forbes.com/sites/greatspeculations/2021/03/01/is-vaxart-stock-set-to-decline-further/?sh $=4590 \mathrm{c} 2251 \mathrm{aba}$ 
Trefis Team. (2021, April 29). Should You Buy Gilead Stock At \$65? Retrieved from Forbes: https://www.forbes.com/sites/greatspeculations/2021/04/29/should-you-buy-gilead-stock-at$65 / ? \mathrm{sh}=63 \mathrm{~d} 08 \mathrm{e} 231672$

UW Applied Biotechnology,“What Is Biotechnology?” 21 Apr. 2021, Retrieved from appliedbiotechnology.wisconsin.edu/about-applied-biotechnology/what-is-biotechnology/.

VAXART. (2020, October 14). Vaxart Announces Positive Hamster Challenge Study Data for its Oral COVID-19 Vaccine. Retrieved from VAXART: https://investors.vaxart.com/news-releases/news-release-details/vaxartannounces-positive-hamster-challenge-study-data-its-oral

Wee, S.-L., Corum, J., \& Zimmer, C. (2021, June 10). Coronavirus Vaccine Tracker. Retrieved from The New York Times: https://www.nytimes.com/interactive/2020/science/coronavirus-vaccine-tracker.html

World Health Organisation. (2021). Influenza A (H1N1) outbreak. Retrieved from World Health Organisation: https://www.who.int/emergencies/situations/influenza-a-(h1n1)-outbreak

World Health Organization. (2021). WHO Coronavirus (COVID-19) Dashboard. Retrieved from World Health Organisation: https://covid19.who.int/ 